UDC 332.363

\title{
ANALYSIS OF THE PREREQUISITES OF THE STANDARDIZATION OF LAND MANAGEMENT DOCUMENTATION
}

\author{
Avramchuk B, Ph.D., \\ Institute of Land Use of NAAS of Ukraine, \\ e-mail:avramchuk.bogdan@gmail.com
}

Kharitonenko R , Ph.D., Institute of Land Use of NAAS of Ukraine, e-mail: kharytonenkor@gmail

Patiyuk $\boldsymbol{O}$., postgraduate student, Institute of Land Use of NAAS of Ukraine, e-mail:o.patiyuk@gmail.com

Lashkevych $\mathrm{O}$, Master, Institute of Land Use of NAAS of Ukraine, e-mail: studentlashkevich @ gmail

The authors developed twelve land management projects for the allocation of land plots to individuals and submitted them for approval to the territorial body of the central body of executive power, which implements state policy in the field of land relations.

The peculiarity of the study is that the developed projects are identical in terms of location of land (adjacent land users), purpose, soil, composition of land and restrictions and burdens on their use. However, the responses of the territorial body of the central executive body implementing the state policy in the field of land relations to the consideration of each of these projects are different, despite the fact that the aforementioned land management projects were developed using the same methods, software and the same contractors.

The lack of a unified system of standards for the development of land documentation and its constituent parts, as well as the criteria for reviewing and evaluating the compliance of such documentation with the territorial bodies of the central executive body implementing state policy in the field of land relations, is a key obstacle to a transparent land management process.

This, in turn, creates the need to analyze the preconditions for standardization of documentation on land management and its components.

Keywords: land management documentation, land management, land management project, standardization. 
Problem statement . According to Article $186^{\prime}$ of the Land Code of Ukraine, $\mathrm{Mr}$ ith the development of land management projects on land allocation the ownership of individuals authors as one of the developers of land documents as part of the Institute of Land Use National Academy of Agrarian Sciences of Ukraine, was given twelve developed projects for approval to the regional body of the central body of executive power, which implements state policy in the field of land relations [4].

However, despite the fact that the developed projects are identical in terms of location of land (adjacent land users), purpose, soil cover, composition of land and restrictions and burdens in their use, and that they were created by the same contractors for by the same methodologies, the responses on the consideration of these projects by the territorial body of the central body of executive power implementing the state policy in the field of land relations were different.

According to the authors, the lack of a unified system of standards for the development of land documentation and its components, as well as the criteria for reviewing and assessing the correspondence of such documentation by the territorial bodies of the central executive body, which implements state policy in the field of land relations, is a key obstacle for transparency and transparency. and the displacement of shadow schemes for harmonizing documentation with land management.

Analysis of recent research and publications. Legislative acts in Ukraine provide for the regulation of monetary valuation of land plots [6, 7], as well as standardization and normalization in the field of land protection and reproduction of soil fertility [4] . However, there are no standards and norms for the development of land use documentation.

It should be noted that in separate regulatory documents there are samples of components of land management documentation - technical tasks for the development of documentation $[5,8,9]$, and documents for making corrections to the information of the State Land Cadastre [3].

Regarding scientific research, standardization and normalization in land management were investigated by Tretyak AM, Tretyak VM, Martin AG, Kolganova 
IG. [10, 11]. Dorosh J.M. and Dorosh OS. in 2015, they considered the issues of state standards of rules and regulations as a mechanism for shaping the institutional environment of territorial land use planning to ensure sustainable development [1].

The purpose of the article is to analyze the background and problematic issues that arise from the lack of common standards for the development of land documentation and its constituent parts.

Main material. As noted above, after considering twelve identical land management projects for the allocation of land to individuals by different territorial bodies of the central body of executive power, which implements state policy in the field of land relations (on the principle of extraterritoriality), various types of remarks were made.

First of all, it should be noted that four land development projects were agreed, while the other eight were returned with observations. This is, first of all, indicative of the lack of a systematic approach to the approval and verification of land management documentation.

The comments that came with the projects that were not agreed were divided into several types by the authors, namely:

- composition of lands;

- restrictions and burdens on land use;

- information on the cadastral plan;

- procedures for establishing and agreeing land boundaries;

- the task of performing works on land management.

Regarding the first type of remarks, it is worth noting that the comments of the territorial bodies of the central executive body implementing state policy in the field of land relations do indeed take place.

Table 1

\section{Comments on land composition}

\begin{tabular}{|c|l|}
\hline o & Remark \\
\hline & The project does not define the ownership of the land plot to particularly valuable lands \\
\hline & The project of allotment should be supplemented with information on soils that lie on the land \\
\hline
\end{tabular}




\begin{tabular}{|c|}
\hline plot with the name of the agricultural group code according to Article .. \\
\hline $\begin{array}{l}\text { Provide to the project materials information on the ownership / non-belonging of the land plot } \\
\text { to especially valuable lands in accordance with the Order of the State Committee of Ukraine } \\
\text { for Land Resources No. } 245 \text { of } 06.10 .2003 \text {. "On approval of the list of particularly valuable } \\
\text { soil groups ." }\end{array}$ \\
\hline $\begin{array}{l}\text { In the explanatory note to the project describe the presence (absence) on the projected land } \\
\text { plot of land of nature conservation and other nature conservation, recreational, historical, } \\
\text { cultural, forestry purpose and water fund in order to comply with the requirements of Article } \\
186-1 \text { of the Land Code. }\end{array}$ \\
\hline
\end{tabular}

However, according to the authors, all comments should be supplemented with a reference to paragraph 7 of Article 9 of the Law of Ukraine "On State Expertise of Land Management Documentation", since the above mentioned type of comments relates to the determination of the parcel of land to " especially valuable lands, lands of forestry purpose and land., environmental, health, recreational and historical and cultural purpose" (Table 1) [2].

Table 2

Notices for at bmezhen and encumbrances land use

\begin{tabular}{|c|c|}
\hline 0 & Remark \\
\hline & $\begin{array}{l}\text { List of restrictions to comply with Annex } 6 \text { as amended according to CMU Resolutions } \\
\text { №1051 dated October 17, } 2012 \text { №105 dated February 7, } 2018 .\end{array}$ \\
\hline & $\begin{array}{l}\text { List of restrictions to comply with Annex } 6 \text { of CMU Resolution No. } 1051 \text { of 10/17/12. (with } \\
\text { changes) - no restriction with code } 06.04 \text {. }\end{array}$ \\
\hline & $\begin{array}{l}\text { To complete the cadastral plan of the land plot in accordance with Art. } 11.34 \text { of the Law of } \\
\text { Ukraine "On the State Land Cadastre": to provide up-to-date information on the land plot, } \\
\text { considering that the land plot is allocated at the expense of the reserve lands, to show the } \\
\text { boundaries of the parts of the land plot which are subject to restrictions on the use of the land } \\
\text { plot (no - to state that there is no ) }\end{array}$ \\
\hline & $\begin{array}{l}\text { The list of restrictions on the use of the land plot should be supplemented with clause } 06.04 \text { - } \\
\text { condition for compliance with environmental protection requirements or performance of } \\
\text { certain works in accordance with Annex } 6 \text { of the Cabinet of Ministers Decree No. } 1051 \text { of } \\
\text { October } 14,2012 \text { "On Approval of the Procedure for Keeping the State Land Cadastre", as } \\
\text { amended in accordance with the Cabinet of Ministers Resolutions No. } 105 \text { of 23/11/2016 and } \\
\text { No. } 105 \text { of } 02 / 02 / 2018\end{array}$ \\
\hline & $\begin{array}{l}\text { To revise the List of restrictions on the use of land in accordance with Annex } 6 \text { of the } \\
\text { Procedure for maintaining the State Land Cadastre, approved by the Cabinet of Ministers of } \\
\text { Ukraine Resolution No.1051 of } 17.10 .2012 \text {, as amended on } 07.02 .2018 \text { No.105 (no restriction } \\
\text { code 06.04). }\end{array}$ \\
\hline & $\begin{array}{l}\text { In accordance with Article } 43 \text { of the Law of Ukraine "On the State Land Cadastre", the } \\
\text { cadastral plan of the land plot shows the boundaries of the parts of the land plots, which are } \\
\text { subject to the restrictions on the use of land plots, sublease rights, easements. }\end{array}$ \\
\hline
\end{tabular}




\begin{tabular}{|l|l|}
\hline & Specify a date in the list of restrictions on land use. \\
\hline & $\begin{array}{l}\text { List of restrictions to comply with Annex } 6 \text { as amended according to CMU Resolutions } \\
\text { №1051 dated October 17, } 2012 \text { №105 dated February 7, 2018. }\end{array}$ \\
\hline
\end{tabular}

Regarding the remarks concerning restrictions on the use of land, it should be noted that they have some systematization - so the remarks about the limitation with code 06.04 are available in several projects at the same time. That is, indeed, these observations do occur.

However, as we can see, different territorial authorities reserve the right to differentiate and specify the shortcomings in the land development project regarding land allotment (Table 2).

Table 3

\section{Comments on cadastral information and information}

\begin{tabular}{|l|l|}
\hline o & \multicolumn{1}{|c|}{ Remark } \\
\hline & $\begin{array}{l}\text { Cadastral plan to bring into compliance with the requirements of Article } 34 \text { of the Law of } \\
\text { Ukraine "On State Land Cadastre" (the cadastral plan of the land plot shows the external } \\
\text { land plots of state or communal property), respectively to these norms the interlocutors are } \\
\text { incorrectly specified in the cadastral map, to be brought into line.) 5.6. the cadastral number } \\
\text { of the land plot and the adjacent land plots (cadastral zoning) are provided on the cadastral } \\
\text { plan. }\end{array}$ \\
\hline $\begin{array}{l}\text { In the cadastral plan of the land plot, indicate the cadastral numbers of adjacent land plots (if } \\
\text { available) according to Article 34 of the Law on State Land Cadastre }\end{array}$ \\
\hline $\begin{array}{l}\text { In the cadastral plan of the land plot, in part the landowners (land users and state-owned lands } \\
\text { not issued for ownership or use) are indicated by the landowner, but at the stage of the land } \\
\text { development project approval the specified individual is not yet a land user of the land. } \\
\text { According to item } 2 \text { of Art. } 24 \text { of the Law of Ukraine "On the State Land Cadastre" a } \\
\text { cadastral plan is drawn up when the land plot is formed. According to Art. 11 of the Law on } \\
\text { the State Land Cadastre, information about the objects of the State Land Cadastre at the time } \\
\text { of entering them into the State Land Cadastre must correspond to the existing characteristics } \\
\text { of objects in kind (on the ground). }\end{array}$ \\
\hline To bring into line the data indicated on the cadastral plan of the land plot. \\
\hline $\begin{array}{l}\text { According to Art. 11 of the Law of Ukraine "On the State Land Cadastre", information about } \\
\text { the objects of the State Land Cadastre from the time of their entry into the State Land } \\
\text { Cadastre must correspond to the existing characteristics of objects in kind (on the ground), } \\
\text { determined with accuracy according to state standards, norms and rules, technical regulations. } \\
\text { characteristics of the land plot (for the purpose). }\end{array}$ \\
\hline Cadastral plan to bring in compliance with the requirements of Article 34 of the Law of \\
\hline
\end{tabular}




\begin{tabular}{|l|l|}
\hline Ukraine "On State Land Cadastre" (the cadastral plan of the land plot shows: cadastral \\
number of the land plot, cadastral numbers (if any) of adjacent land plots, external borders of \\
the land plot (with indication of adjacent land plots) sites, their owners, users of adjacent land \\
state or municipal property) so in accordance with these rules allied listed on the cadastral \\
plan incorrectly aligned with) coincidences Vienna to data from the State Land Cadastre land \\
borders on state-owned land that is not generated and is not registered;
\end{tabular}

Most of the comments on the cadastral plan refer to Article 34 of the Law of Ukraine "On the State Land Cadastre", although there are comments without any legal confirmation (Table 3).

In addition, the interpretation of the above Article of the Law territorial authorities also reserve, because, for example, to indicate cadastral numbers of adjacent land plots is necessary in their presence, ie in the absence of such (as was the case in all 12 land management projects considered in this article) - they are not indicated, but a relevant remark is present.

In another, the remarks take place, since indeed adjacent land users have indicated individuals, land allotment has not yet been completed.

Table 4

Notes on Mater and aliv geodetic surveys and establishing the boundaries of land

\begin{tabular}{|l|l|}
\hline o & \multicolumn{1}{|c|}{ Remark } \\
\hline & $\begin{array}{l}\text { The act of acceptance-transfer of boundary marks for storage to agree with the land manager } \\
\text { in accordance with the instruction on the establishment of 9) land boundaries in kind (on the } \\
\text { ground) and their fixing with boundary marks approved by the Order of the State Committee } \\
\text { of Ukraine for Land Resources of 18.05.2010 №376 ( owners, users of adjacent land not fully } \\
\text { specified) }\end{array}$ \\
\hline $\begin{array}{l}\text { In accordance with the requirements of Article 50 of the Law of Ukraine "On Land } \\
\text { Management" to attach to the project of land management materials for the transfer of land } \\
\text { boundaries in nature (terrain) designed in accordance with the requirements of points 3.1, } \\
\text { Instruction on the establishment (restoration) of land boundaries in kind (on the ground) and } \\
\text { their fixing border signs, approved by the Order of the State Land Committee of May 18, } \\
\text { 2010 №376. }\end{array}$ & $\begin{array}{l}\text { The project of land management did not take into account the requirements of the Instruction } \\
\text { on the establishment (restoration) of land boundaries in kind (on the ground) and fixing them } \\
\text { with boundary marks and Article.198 of the Land Code, namely: the boundaries of adjacent } \\
\text { land users, which are indicated on the cadastral plan, were not agreed landscaping project } \\
\text { should include steps of boundary marks (Appendix \# 2) of the Instruction; }\end{array}$ \\
\hline
\end{tabular}




\begin{tabular}{|c|c|}
\hline & $\begin{array}{l}\text { The materials of geodetic surveys and land planning of the land plot do not meet the } \\
\text { requirements of Article } 79-1 \text { of the Land Code of Ukraine (in part regarding the way of land } \\
\text { plot formation) and the requirements of the Procedure of keeping the state land cadastre } \\
\text { (regarding the implementation of design decisions of entering the land plot into the State land } \\
\text { plot), namely: since the projected land plot is formed by dividing the area formed by the land } \\
\text { plot of } 14.2934 \text { hectares, resulting in the implementation of project activities that formation of } \\
\text { land is minimally necessary materials cadastral plans of land formed by dividing the existing } \\
\text { land area of } 14.2934 \text { hectares (after her discharge from the project site) in this project are } \\
\text { available; }\end{array}$ \\
\hline & $\begin{array}{l}\text { Attach full measurement materials in accordance with Art. } 50 \text { Law of Ukraine "On Land } \\
\text { Management" confirming the legitimacy of obtaining data from the state geodetic network } \\
\text { (Article } 20 \text { of the Law of Ukraine "On Topographical-Geodetic and Cartographic } \\
\text { Activities"); }\end{array}$ \\
\hline & $\begin{array}{l}\text { To take into account the requirements of the CMU Resolution No. } 1075 \text { of July 13, } 1998 \text { (as } \\
\text { amended) "On the Procedure of Using Satellite Radio Navigation Systems During } \\
\text { Topographic and Geodetic, Aerial Photographic, Design, Research and Investigation and } \\
\text { Inventory and Cadastre Shooting" State Geocadastre of satellite radio navigation systems } \\
\text { (SRNS equipment); }\end{array}$ \\
\hline & $\begin{array}{l}\text { To refine the materials of geodetic surveys and land-planning design for binding to the points } \\
\text { of the State Land Register, objects and contours of the terrain in accordance with the } \\
\text { Instruction on the establishment (restoration) of boundaries of land and nature (on the terrain) } \\
\text { and fixing them with boundary marks, approved by the Order of the State Committee of land } \\
\text { on } 18.05 .2010 \text { No. } 276 \text {, also to add to the act of acceptance-transfer of boundary marks the } \\
\text { steps of boundary marks. }\end{array}$ \\
\hline & $\begin{array}{l}\text { To agree the boundaries of the land plot in accordance with Art. } 198 \text { of the Land Code of } \\
\text { Ukraine with all adjacent landowners, land users, taking into account their powers in } \\
\text { accordance with Art. } 122 \text { of the Land Code of Ukraine. }\end{array}$ \\
\hline & $\begin{array}{l}\text { Displays information about DHM items, indicating their coordinates, names, and locations } \\
\text { relative to the land. }\end{array}$ \\
\hline 0 & $\begin{array}{l}\text { In accordance with Article } 20 \text { of the Law of Ukraine "On Surveying and Geodetic Activities" } \\
\text { to confirm the legitimacy of obtaining data from the state geodetic network. }\end{array}$ \\
\hline 1 & $\begin{array}{l}\text { The act of acceptance of the transfer of boundary marks to comply with the instruction on the } \\
\text { establishment (restoration) of land boundaries in kind (on the ground) and their fixing with } \\
\text { boundary marks approved by the order of the State Land Committee № } 376 \text { of } 18.05 .2010 \text { (no } \\
\text { steps) }\end{array}$ \\
\hline 2 & $\begin{array}{l}\text { According to clause } 3.1 \text { of the Instruction on the establishment (restoration) of land } \\
\text { boundaries in kind (on the ground) and their fixing with boundary marks, approved by the } \\
\text { Order of the State Land Committee of May 18, } 2010 \text { No. } 376 \text { to specify types of boundary } \\
\text { marks ( } 1,2 \text { or } 3 \text { types). }\end{array}$ \\
\hline
\end{tabular}

This type of comment can, in turn, be divided into subtypes:

- approval of the boundaries of the land plot; 
- information regarding the attachment to the points of the State Geodetic Network;

- fixing the boundaries of the land plot with boundary marks;

- other.

Concerning the harmonization of land boundaries with adjacent landowners, there is indeed a comment on existing adjacent land users rather than project landmarks that were specified in land management projects. However, in accordance with paragraph 2.1 of "Instruction on the establishment (restoration) of land boundaries in nature (the field) and their consolidation boundary marks": "Establishing the limits of land plots in kind (on location) on the basis of developed and approved the technical documentation land management on establishment (restoration) of the boundaries of the land plot in kind (on the ground), technical documentation of the land management regarding the division and association of the land plots or the project of the land management concerning the land allotment" [5].

That is, at the stage of approval of the project of land management there are no grounds for establishing (as well as agreeing) the boundaries of the land plot (Table $4)$.

Regarding the information on the annexation to the points of the State Geodetic Network - a comment has been made, since it was not provided to the full extent in the land development projects.

There are also several remarks regarding the bounding of land boundaries with boundary marks, namely the requirement to indicate the steps of boundary marks.

In accordance with Annex 2 of the Instruction on the Establishment (Restoration) of Land Boundaries in Nature (on the Territory) and their Fixing with Border Marks, the outlines (steps) [5] are added to the Act of Acceptance-Transfer of Border Marks.

That is, the interpretation of this statement remains with the territorial authorities, since outlines of boundary marks have been added to the land management projects, which the authors interpreted as one of two sufficient documents. 


\section{Remarks on the task of the works}

\begin{tabular}{|c|l|}
\hline o & \multicolumn{1}{|c|}{ Remark } \\
\hline & $\begin{array}{l}\text { The task to perform the works is to comply with the requirements of the Cabinet of Ministers } \\
\text { of Ukraine of 26.03.2004 No.266 "On approval of a standard contract for the development of } \\
\text { a land development project for land allotment" (stating that the task is an integral part of the } \\
\text { contract for the performance of works); }\end{array}$ \\
\hline $\begin{array}{l}\text { The technical task is to comply with the resolution of the Cabinet of Ministers №266 of } \\
\text { 04.03.2004. }\end{array}$ \\
\hline
\end{tabular}

It is worth noting that in the development of land management projects considered in this article, it was CMU Resolution No. 266 of 04.03.2004 that was used to write the task for the execution of works.

An important issue remains that only two of the twelve land management projects regarding the allotment of land to individuals were addressed in this land use documentation.

In addition, there is some inconsistency in the use of terms in accordance with applicable law. Thus, the CMU Resolution No. 266 of March 4, 2004 established a model Task for performance of works, although there is a remark on the Terms of Reference (Table 5), in addition, in accordance with Article 50 of the Law of Ukraine "On Land Management", in the composition of the land management project for allotment of land is included The task of developing a land management project.

Obviously, the use of three different names of components of land management documentation creates difficulty in agreeing such.

Conclusion. Considering the responses of the territorial bodies of the central body of executive power, which implements the state policy in the field of land relations about the approval of land development projects for the allocation of land plots to the property of individuals, first of all, we can state that most of the comments take place.

However, these comments are not systematic and of a consistent nature. That is, after analyzing the prerequisites and problematic issues that arise in the development and coordination of land management documentation, it should be 
emphasized that due to the lack of common standards for the development of documentation on land management and its constituent parts, unsystematic and varied remarks about identical types of documentation will be produced.

In order to have a fundamental approach to solving the problem under study, according to the authors, it is necessary to develop common standards for the development of land management documentation on the basis of State Standards and Requirements 3008-95 "Documentation. Reports in the field of science and technology", as well as the standards of individual components of the documentation on land management, taking into account the requirements of existing regulations.

\section{References}

1. Dorosh Y.M., Dorosh O.S. (2015) Derzhavni standarty, normy i pravyla yak mekhanizm formuvannia instytutsionalnoho seredovyshche terytorialnoho planuvannia zemlekorystuvannia [ State standards, rules and regulations as a mechanism for is shaping the institutional environment of land use territorial planning]. Zemleustrii, cadastre and monitorynh zemel. Vol. 2/3. 3-12.

2. The Verkhovna Rada of Ukraine (2004). The Law of Ukraine " On State Examination of Land Management Documentation". Available at: https://zakon.rada.gov.ua/laws/show/1808-15.

3. The Verkhovna Rada of Ukraine (2001). The Law of Ukraine "On the State Land Cadastre". Available at: http://zakon.rada.gov.ua/laws/show/3613-17\#n369.

4. The Verkhovna Rada of Ukraine (2002), The Law of Ukraine "Land Code of Ukraine", Vidomosti Verkhovnoi Rady Ukrainy, vol. 3-4, 27.

5. State Committee for Land Resources (2010) Order of the State Committee for Land Resources "On approval of the Instruction on the establishment (restoration) of land boundaries in kind (on the ground) and their fixing with boundary marks." Available at: https://zakon.rada.gov.ua/laws/show/z0391-10 .

6. Cabinet of Ministers of Ukraine (2003), "Resolution of the Cabinet of Ministers of Ukraine number 1440 « On Approval of National Standard No.1 
“General Principles of Property and Property Rights Valuation". Available at: http: zakon2.rada.gov.ualawsshow1440-2003-\% D0\% BF.

7. Cabinet of Ministers of Ukraine (2004), "Resolution of the Cabinet of Ministers of Ukraine number 1442 «On Approval of the National Standard No.2 "Valuation of Real Estate". Available at: http://zakon2.rada.gov.ualawsshow14422004-\% D0\% BF.

8. Cabinet of Ministers of Ukraine (2019), "Resolution of the Cabinet of Ministers of Ukraine No. 476 "On Approving the Procedure for Land Inventory and Recognition of Some Decisions of the Cabinet of Ministers of Ukraine". Available at: https://zakon.rada.gov.ua/laws/show/476-2019-\%D0\%BF.

9. Cabinet of Ministers of Ukraine (2004), "Resolution of the Cabinet of Ministers of Ukraine No. 266 "On Approval of the Model Agreement on the Development of the Land Management Project for Land Allocation”. Available at: https://zakon.rada.gov.ua/laws/show/266-2004-\%D0\%BF.

10. Tretiak A.M., Druhak V.M., Kolhanova I.H. (2013) Standartyzatsi ia ta normuvannia u zemleustroi : navch . posib [ Standardization and Rationing in Land Management : Tutorial tool ]. Kyiv. "Agroosvita". 233 p.

11. Tretiak A.M., Martyn A.H., Dorosh Y.M. (2008) Standartyzatsiia pohodzhennia dokumentatsii iz zemleustroiu: vymohy do protsedury ta zmistu vysnovkiv [Standardization of harmonization of land management documentation: requirements for procedure and content of conclusions]. Zemlevporiadnyi visnyk. Vol 3. 25-30.

$* * *$

Аврамчук Б.О., Харитоненко Р.А., Патіюк О.О., Лашкевич О.В.

АНАЛІЗ ПЕРЕДУМОВ СТАНДАРТИЗАЦӤ̈ ДОКУМЕНТАЦӤ ІЗ ЗЕМЛЕУСТРОЮ

Авторами було розроблено дванадиять проектів землеустрою щуодо відведення земельних ділянок у власність фізичним особам та подано на погодження до територіального органу центрального органу виконавчої влади, щүо реалізує державну політику у сфері земельних відносин.

Особливість дослідження полягає в тому, що розроблені проекти є ідентичними з точки зору місия розташування земельних ділянок (суміжні землекористувачі), цільового 
призначення, трунтового покриву, складу угідь та обмежень і обтяжень у їх використання. Проте відповіді територіального органу центтрального органу виконавчої влади, щэо реалізує державну політику у сфері земельних відносин на розгляд кожного з иих проектів є різними, незважаючи на те, щуо вищезгадані проекти землеустрою розроблялися за однаковими методиками, програмним забезпеченням та одними виконавцями.

Відсутність єдиної системи стандартів щуодо розробки землевпорядної документащії та ї складових частин, а також критерїв розгляду та оичінки відповідності такої документації територіальними органами цฺентрального органу виконавчої влади, щуо реалізує державну політику у сфері земельних відносин, є ключової перепоною для прозорого землевпорядного процесу.

Це, у свою чергу, породжує необхідність аналізу передумов щэодо стандартизаиіі документації із землеустрою та ї̈ складових частин.

Ключові слова: документація із землеустрою, землевпорядкування, проект землеустрою, стандартизаичія.

$$
* * *
$$

Аврамчук Б.О., Харитоненко Р.А., Патиюк О.О., Лашкевич О.В.

АНАЛИЗ ПРЕДПОСЫЛОК СТАНДАРТИЗАЦИИ ДОКУМЕНТАЦИИ ПО ЗЕМЛЕУСТРОЙСТВУ

Авторами было разработано двенадиать проектов землеустройства по отводу земельных участков в собственность физическим лицам и представлен на согласование в территориальный орган центрального органа исполнительной власти, реализующего государственную политику в сфере земельных отномений.

Особенность исследования состоит в том, что разработанные проекты являются идентичными с точки зрения местоположения земельных участков (смежные землепользователи), целевого назначения, почвенного покрова, состава угодий и ограничений и обременений в их использования. Однако ответа территориального органа центрального органа исполнительной власти, реализующего государственную политику в сфере земельных отношений на рассмотрение каждого из этих проектов разные, несмотря на то, что вымеупомянутые проекты землеустройства разрабатывались по одинаковым методикам, программным обеспечением и одними исполнителями.

Отсутствие единой системь стандартов по разработке землеустроительной документациии и ее составных частей, а также критериев рассмотрения и оценки соответствия такой документации территориальными органами центрального органа 
исполнительной власти, реализующего государственную политику в сфере земельных отношений, является ключевой преградой для прозрачного землеустрочтельного прочесса.

Это, в свою очередь, порождает необходимость анализа предпосылок стандартизации документащии по землеустройству и ее составных частей.

Ключевые слова: документация по землеустройству, землеустройство, проект землеустройства, стандартизащия. 